\title{
PERBANDINGAN PRAKTIK PRAPERADILAN DAN PEMBENTUKAN HAKIM PEMERIKSA PENDAHULUAN DALAM PERADILAN PIDANA INDONESIA*
}

\author{
Fachrizal Afandi** \\ Bagian Hukum Pidana, Fakultas Hukum Universitas Brawijaya, Malang \\ Jalan M.T. Haryono, No. 169 Malang, Jawa Timur
}

\begin{abstract}
This article aims to identify and analyze the conception and practice of the object pre-trial expansion in Indonesia based on several court verdicts and the second is to compare pretrial in the Code of Criminal Procedure Law that prevail and Preliminary Examining Judge in the draft of Criminal Procedure Code. The research shows that pre-trial authority expansion can be understood as a judicial authority effort to check the investigator or prosecutor in upholding the code of criminal procedure. Hence, when comparing the pretrial procedure and the Preliminary Examining Judge.
\end{abstract}

Keywords: pretrial, law enforcement, preliminary examining judge.

\section{Intisari}

Tulisan bertujuan untuk melakukan analisis praktik perluasan obyek praperadilan di Indonesia dan melakukan perbandingan praperadilan dalam Kitab Undang-undang Hukum Acara Pidana (KUHAP) dengan HPP dalam rancangan KUHAP. Hasil penelitian menunjukkan bahwa praktik perluasan kewenangan praperadilan dapat dipahami sebagai upaya kekuasaan yudisial menguji keabsahan upaya paksa yang dilakukan oleh penyidik. Meskipun demikian, dengan kewenangan yang masih terbatas dan sifatnya yang pasif, praperadilan dipandang kurang efektif dalam mengawasi upaya paksa yang dilakukan aparat penegak hukum.

Kata Kunci: pra peradilan, penegakan hukum, hakim pemeriksa pendahuluan.

\section{Pokok Muatan}

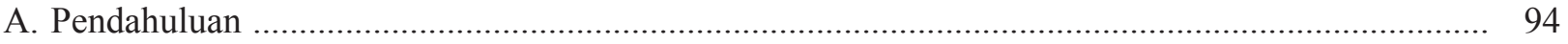

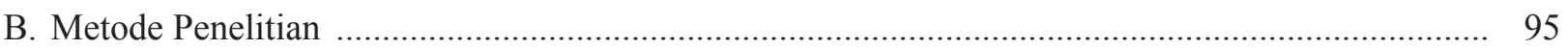

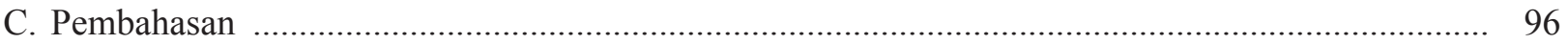

1. Perluasan Kewenangan Praperadilan dalam Sistem Peradilan Pidana Indonesia ...................... 96

2. Perluasan Obyek Praperadilan dalam Beberapa Putusan Pengadilan .................................... 98

3. Lembaga Praperadilan vis a vis Pembentukan Lembaga Hakim Pemeriksa Pendahuluan ......... 101

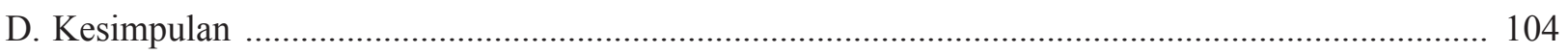

Hasil Penelitian Hasil Penelitian DPP SPP BPPK FH UB yang didanai oleh BOPTN Kemenristek Dikti Tahun Anggaran 2015.

***Alamat Korespondensi: fachrizal@ub.ac.id atau fachrizal.afandi@gmail.com 


\section{A. Pendahuluan}

Perbincangan hangat tentang perlunya penguatan pengawasan pada keabsahan tindakan oleh lembaga peradilan yang mengemuka akhirakhir ini salah satunya dipicu oleh penyalah gunaan wewenang dalam melakukan upaya paksa yang berujung pada adanya dugaan "kriminalisasi" (malicious prosecution) yang dilakukan oleh oknum aparat penegak hukum. ${ }^{1}$

Satu-satunya lembaga yang kita kenal sejak tahun 1981 melalui Undang-Undang Nomor 8 Tahun 1981 tentang Kitab Undang-Undang Hukum Acara Pidana (KUHAP) untuk menguji keabsahan upaya paksa yang dilakukan oleh aparat penegak hukum secara terbatas adalah lembaga praperadilan. ${ }^{2}$ Meskipun dalam perjalanannya lembaga praperadilan dianggap kurang efektif dalam menjamin hak asasi warga negara yang berhadapan dengan kekuasaan represif oknum aparat penegak hukum. ${ }^{3}$

Riset yang dilakukan oleh Institute for criminal Justice Reform (ICJR) pada tahun 2014 di beberapa kota di Indonesia menunjukkan bahwa dari data yang didapat hampir 85 persen gugatan praperadilan ditolak oleh pengadilan negeri dengan berbagai macam alasan. ${ }^{4}$ Hambatanhambatan dalam pemeriksaan praperadilan yang mengakibatkan kurangnya realisasi hak-hak asasi khususnya terkait implementasi habeas corpus dalam lembaga praperadilan menjadikan lembaga ini dipandang kurang efektif dalam melakukan pengawasan tindakan aparat lembaga peradilan.

Di sisi lain seiring dengan berjalannya waktu dapat ditemukan terdapat beberapa putusan praperadilan yang telah berkekuatan hukum tetap yang memperluas kewenangan praperadilan dalam melakukan uji keabsahan upaya paksa di luar ketentuan yang termaktub dalam KUHAP. ${ }^{5}$ Bahkan terakhir yang menjadi kontroversial adalah putusan pra peradilan Pengadilan Negeri Jakarta Selatan yang memeriksa dan memutus keabsahan penetapan tersangka yang dilakukan oleh Komisi Pemberantasan Korupsi terhadap Komisaris Jenderal Polisi Budi Gunawan. ${ }^{6}$

Tak lama berselang, Mahkamah Konstitusi Republik Indonesia melalui putusan Nomor 21/PUU-XII/2014 memperluas kewenangan praperadilan dalam Pasal 77 KUHAP termasuk juga dalam memeriksa dan memutus sah atau tidaknya penetapan tersangka, penggeledahan dan penyitaan. Putusan Mahkamah Konstitusi ini menimbulkan harapan baru utamanya bagi para pencari keadilan untuk dapat melakukan uji keabsahan upaya paksa dari oknum penegak hukum. Hal yang menunjukkan adanya perkembangan hukum di masyarakat yang menginginkan adanya perluasan kewenangan praperadilan dalam melakukan pengawasan yudisial atas tindakan-tindakan yang berpotensi melanggar Hak Asasi Manusia dalam sistem peradilan pidana Indonesia.

Sejatinya jauh sebelum penerapan lembaga praperadilan, sistem peradilan pidana di Indonesia telah mengenal lembaga hakim komisaris yang memiliki tugas mengawasi upaya paksa yang dilakukan oleh aparat penegak hukum sebagaimana diatur dalam Reglement op de Strafvoerdering (RV). Namun pilihan menggunakan Herziene Indische Reglement (HIR) dengan Staatsblad No. 44 Tahun 1941 sebagai hukum acara yang berlaku sejak Indonesia merdeka mengakibatkan lembaga

Muhammad Khairur Rasyid, "Kontras Gelar Perkara Terbuka Korban Kriminalisasi”, http://Jatim.Metrotvnews.Com/Read/2015/09/15/431457/ Kontras-Gelar-Perkara-Terbuka-Korban-Kriminalisasi, diakses 12 Oktober 2015.

Pasal 1 ke 10 jo Pasal 77 KUHAP membatasi kewenangan pra peradilan hanya dalam hal memeriksa dan memutus sah atau tidaknya suatu penangkapan dan atau penahanan, sah atau tidaknya penghentian penyidikan atau penghentian penuntutan, dan permintaan ganti kerugian atau rehabilitasi.

Anonim, "Penelitian KHN: Praperadilan Mengandung Banyak Kelemahan", http://www.hukumonline.com/berita/baca/lt4b29bab9ef3a7/ penelitian-khn-praperadilan-mengandung-banyak-kelemahan, diakses 12 Oktober 2015.

Anggara, et al., 2014, Praperadilan di Indonesia: Teori, Sejarah dan Praktiknya, Institute for Criminal Justice Reform, Jakarta, hlm. 64. Anonim, "Metamorfosis Wajah Praperadilan", http://www.hukumonline.com/berita/baca/lt55716335453cd/metamorfosis-wajah-praperadilan, diakses 25 September 2015.

"Anonim, "Putusan Praperadilan Komjen BG Kontroversial MA Harus Berani Mengujinya", http://news.detik.com/berita/2841011/putusanpraperadilan-komjen-bg-kontroversial-ma-harus-berani-mengujinya, diakses 12 Oktober 2015. 
ini tidak dikenal dan tidak ada model pengawasan horizontal yang dapat melakukan uji keabsahan upaya paksa yang dilakukan oleh aparat penegak hukum sampai diberlakukannya KUHAP pada tahun 1981 ? $^{7}$

Usaha memasukkan lembaga Hakim komisaris dalam KUHAP ini sebenarnya pernah diajukan dalam Rancangan Undang-undang Hukum Acara Pidana tahun 1974 oleh Prof. Oemar Seno Adjie, S.H., yang saat itu menjabat sebagai Menteri Kehakiman. Konsep hakim komisaris ini mirip dengan konsep yang pernah ada dalam Reglement op de Strafvoerdering. Namun sayang dalam perkembangannya, gagasan hakim komisaris tersebut kemudian dianulir oleh Sekretariat Negara yang kemudian diganti dengan lembaga praperadilan. ${ }^{8}$

Pada tahun 2012 yang lalu konsep lembaga Hakim Komisaris muncul kembali dalam RUU KUHAP yang dibahas Dewan Perwakilan Rakyat dengan nama yang berbeda yaitu Hakim Pemeriksa Pendahuluan. Munculnya kembali konsep lembaga hakim komisaris/hakim pemeriksa pendahuluan ini dapat dipahami sebagai bentuk keinginan pembuat undang-undang untuk lebih memperkuat pelembagaan pengawasan horizontal upaya paksa yang dilakukan oleh aparat penegak hukum. Hal yang pada gilirannya diharapkan akan memiliki impilikasi besar pada perlindungan hak asasi manusia warga negara yang sedang berhadapan maupun berkonflik dengan hukum. ${ }^{9}$

Dari berbagai latar berlakang di atas, setidaknya ada dua isu utama yang diteliti dalam penelitian ini, yakni: Pertama, terkait konsepsi dan praktik perluasan obyek pra peradilan di Indonesia berdasarkan beberapa putusan pengadilan yang telah berkekuatan hukum tetap. Kedua tentang kelemahan dan kelebihan konsep lembaga praperadilan jika dibandingkan konsep lembaga Hakim Pemeriksa Pendahuluan sebagai lembaga pengawas horizontal dalam Rancangan Kitab Undang-Undang Hukum Acara Pidana rencananya akan dibahas ulang dalam Program Legislasi Nasional periode pemerintahan Presiden Joko Widodo ini. ${ }^{10}$

\section{B. Metode Penelitian}

Untuk menjawab permasalahan yang dikemukakan pada bagian sebelumnya, penelitian ini dilakukan dengan pendekatan hukum normatif, yaitu dengan cara melakukan penelaahan kritis dan mendalam terhadap bahan-bahan pustaka dan dokumen-dokumen hukum yang relevan dengan isu praperadilan dan hakim pemeriksa pendahuluan.

Peneliti mendekati permasalahan yang diteliti setidaknya dengan tiga pendekatan, pertama pendekatan konseptual (conseptual approach), kedua pendekatan perundang-undangan (statue approach), dan terakhir pendekatan kasus (case approach). Pendekatan konseptual dilakukan dengan mengkaji beberapa konsep hukum terkait model pengawasan horizontal dalam sistem peradilan pidana yang telah dikaji dan diteliti oleh para akademisi hukum pidana dalam beberapa literatur. ${ }^{11}$ Pendekatan ini digunakan untuk mempermudah peneliti dalam memahami konteks permasalahan. Konsep-konsep seperti konsep perlindungan Hak Asasi Manusia dalam sistem peradilan pidana dan konsep pengawasan penegakan hukum akan dijadikan bahan hukum sekunder yang akan membantu peneliti dalam melakukan analisa permasalahan. Selanjutnya pendekatan perundangundangan (statue approach) dilakukan dengan cara menganalisis dan mengevaluasi peraturan perundang-undangan termasuk aturan pelaksana

Loebby Loeqman, 1987, Pra Peradilan di Indonesia, Ghalia Indonesia, Jakarta, hlm 47-48.

Andi Hamzah dan R.M. Surachman, 2015, Pre-Trial Justice and Discretionary Justice dalam KUHAP Berbagai Negara, Sinar Grafika, Jakarta hlm. 36-40.

Istilah berhadapan dan berkonflik dengan hukum ini penulis adaptasi dari Pasal 1 Undang-Undang Nomor 11 Tahun 2012 tentang Sistem Peradilan Pidana. Kedua diksi ini menurut penulis mewakili status warga negara yang terlibat dalam sistem peradilan pidana.

10 Moyang Kasih Dwimerdeka, “36 RUU Lama Kembali Masuk Prolegnas 2015”, http://nasional.tempo.co/read/news/2015/02/03/078639666/36ruu-lama-kembali-masuk-prolegnas-2015, diakses 25 September 2015.

11 Johni Ibrahim, 2007, Teori dan Metodologi Penelitian Hukum Normatif, Bayu Media Publishing, Malang, hlm. 306. 
teknis yang mengikat penegak hukum dalam mekanisme pengawasan horizontal dalam sistem peradilan pidana. ${ }^{12}$ Terakhir, peneliti akan berusaha mempertajam jawaban permasalahan dengan melakukan studi kasus (cases study approach) dengan mempelajari beberapa putusan praperadilan yang memperluas kewenangan objek praperadilan. ${ }^{13}$

\section{Pembahasan}

\section{Perluasan Kewenangan Praperadilan} dalam Sistem Peradilan Pidana Indonesia

Loebby Loeqman mendefinisikan Sistem Peradilan Pidana sebagai suatu rangkaian antara unsur atau faktor yang saling terkait satu dengan lainnya sehingga menciptakan suatu mekanisme sedemikian rupa sehingga sampai tujuan dari sistem tersebut yaitu untuk mencapai suatu masyarakat yang terbebas dari kejahatan. ${ }^{14}$

Pada dasarnya sebagai negara yang tatap mempertahankan sebagian besar hukum kolonial Belanda, Indonesia menganut sistem peradilan pidana inquisitorial. Namun sejak diberlakukannya Undang-Undang Nomor 8 Tahun 1981 tentang Kitab Undang-Undang Hukum Acara Pidana, sistem peradilan pidana Indonesia memiliki beberapa konsep dan prinsip sistem adversarial dalam pengaturannya. ${ }^{15}$ Salah satu konsep sistem adversarial yang digunakan dalam KUHAP adalah konsep pra peradilan yang merupakan adopsi dari konsep Habeas Corpus Act (1679) yang lahir di Inggris. ${ }^{16}$

Praperadilan merupakan satu mekanisme hukum acara pidana yang dapat ditempuh untuk menguji keabsahan tindakan aparat penegak hukum. Secara normatif diyakini bahwa objek kewenangan praperadilan bersifat limitatif yang terbatas hanya pada apa yang diuraikan dalam Pasal 1 angka 10 dan Pasal 77 Undang-Undang Nomor 8 Tahun 1981 tentang Kitab Undang-Undang Hukum Acara Pidana. Hal yang juga senada dengan ketentuan Pasal 9 ayat (4) ICCPR yang menyatakan bahwa pengadilan dapat memutuskan penundaan mengenai keabsahan penahanannya dan memerintahkan pembebasan apabila penahanan itu tidak sah, untuk alasan-alasan yang sama seperti mengenai jangka waktu penahanan yang harus dibatasi dengan ketat, orang yang ditangkap atau ditahan harus diberi hak untuk membawa pengaduannya kepada sidang pengadilan. ${ }^{17}$

Secara rinci, jika dirunut sesuai dengan ketentuan yang termaktub dalam KUHAP kewenangan Praperadilan adalah wewenang Pengadilan Negeri untuk memeriksa dan memutus: ${ }^{22}$

a. Sah/tidaknya penangkapan, penahanan, penghentian penyidikan atau penghentian penuntutan (kecuali terhadap penyampingan perkara untuk kepentingan umum oleh Jaksa Agung); ${ }^{18}$ (Pasal 77);

b. Ganti kerugian dan/atau rehabilitasi bagi seorang yang perkara pidananya dihentikan pada tingkat penyidikan atau penuntutan; ${ }^{19}$

c. Sah atau tidaknya benda yang disita sebagai alat bukti; ${ }^{20}$

d. Tuntutan ganti kerugian oleh tersangka atau ahli warisnya atas penangkapan atau penahanan serta tindakan lain tanpa alasan yang berdasarkan undang-undang atau karena kekeliruan mengenai orang atau karena kekeliruan mengenai hukum yang diterapkan yang perkaranya tidak diajukan ke

Ibid., hlm. 301.

Ibid., hlm. 321.

Loebby Loeqman, 2002, Hak Asasi Manusia (HAM) dalam Hukum Acara Pidana (HAP), Datacom, Jakarta, hlm. 19.

Robert R Strang, "More Adversarial, But Not Completely Adversarial: Reformasi of the Indonesian Criminal Procedure Code", Fordham International Law Journal, Vol. 32, Nomor 188, Tahun 2008.

6 M. Yahya Harahap, 2007, Pembahasan dan Permasalahan dan Penerapan KUHAP (Penyidikan dan Penuntutan), Sinar Grafika, Jakarta, hlm. 69.

17 A.C.'t Hart, et al., Hukum Acara Pidana (dalam Prespektif Hak Asasi Manusia), LBH Jakarta, Jakarta, hlm. 38.

18 Lebih lanjut lihat Pasal 77 Kitab Undang-Undang Hukum Acara Pidana (KUHAP) (Lembaran Negara Republik Indonesia Tahun 1981 Nomor 76, Tambahan Lembaran Negara Nomor 3209).

9 Ibid.

20 Lebih lanjut lihat Pasal 82 ayat (1) dan (3) Kitab Undang-Undang Hukum Acara Pidana (KUHAP) (Lembaran Negara Republik Indonesia Tahun 1981 Nomor 76, Tambahan Lembaran Negara Nomor 3209). 
$\mathrm{PN} ;{ }^{21}$

e. Permintaan rehabilitasi oleh tersangka atas penangkapan atau penahanan tanpa alasan berdasarkan undangundang atau kekeliruan mengenai orang atau hukum yang diterapkan yang perkaranya tidak diajukan ke PN.

Namun demikian semangat praperadilan sebagai lembaga untuk melindungi hak asasi manusia warga negara yang berhadapan atau berkonflik dengan hukum mengilhami beberapa putusan pengadilan negeri yang memperluas obyek pemeriksaan praperadilan tidak hanya terbatas pada ketentuan Pasal 1 angka 10 dan Pasal 77 KUHAP.

Salah satu contohnya adalah putusan Pengadilan Negeri Jakarta Selatan pada November 2012 silam yang mengabulkan permohonan praperadilan tersangka kasus korupsi bioremediasi, Bachtiar Abdul Fatah. Hakim Suko Harsono menyatakan penetapan tersangka tidak sah, tetapi menolak mengabulkan permintaan pemohon agar penyidikan dihentikan. ${ }^{23}$

Putusan serupa yang kontroversial adalah putusan praperadilan yang diputuskan oleh Hakim Sarpin Rizaldi yang menyatakan ketidak absahan penetapan tersangka oleh Komisi Pemberantasan Korupsi kepada Komisaris Jendral Polisi Budi Gunawan. Beberapa pihak menilai putusan praperadilan ini merupakan suatu kekeliruan yang nyata dan melebihi kewenangannya, karena kewenangan untuk mengisi kekosongan hukum acara atau membuat pengaturan tentang penyelesaian suatu soal yang belum diatur dalam hukum acara termasuk menafsirkan pelaksanaan hukum acara itu ada di Mahkamah Agung. ${ }^{24}$
Selain soal penetapan tersangka pada tahun 2010 hakim Pengadilan Negeri Jakarta Pusat juga pernah membuat putusan yang menerobos Pasal 77 KUHAP. Hakim mengabulkan permohonan praperadilan atas penanganan perkara yang berlarutlarut. Dalam amarnya Hakim memerintahkan jaksa segera melimpahkan perkara dengan argumentasi bahwa ketidakjelasan proses yang berlangsung selama bertahun-tahun mengakibatkan ketidakpastian hukum. ${ }^{25}$

Kontroversi perluasan obyek praperadilan ini akhirnya dilegitimasi oleh Mahkamah Konstitusi (MK) melalui Putusan Nomor 21/PUU-XII/2014 yang memperluas kewenangan praperadilan dalam Pasal 77 KUHAP dengan menambahkan kewenanganan praperadilan dalam memeriksa dan memutus sah atau tidaknya penetapan tersangka, penggeledahan dan penyitaan. Putusan ini juga memperjelas definisi bukti permulaan, bukti permulaan yang cukup, dan bukti yang cukup dalam Pasal 1 angka 14, Pasal 17, dan Pasal 21 ayat (1) KUHAP dengan dimaknai minimal dua alat bukti sesuai Pasal 184 KUHAP. ${ }^{26}$

Dasar pertimbangan MK dalam putusan ini adalah karena KUHAP tidak memiliki check and balance system atas tindakan penetapan tersangka oleh penyidik yang disebabkan tidak adanya mekanisme pengujian atas keabsahan perolehan alat bukti. ${ }^{27}$ Hakikat keberadaan pranata praperadilan adalah bentuk pengawasan dan mekanisme keberatan terhadap proses penegakan hukum yang terkait erat dengan jaminan perlindungan hak asasi manusia. Namun dalam perjalanannya, lembaga praperadilan tidak mampu menjawab permasalahan yang ada dalam proses pra-ajudikasi karena dibatasi

\footnotetext{
Lebih lanjut lihat Pasal 95 ayat (2) Kitab Undang-Undang Hukum Acara Pidana (KUHAP) (Lembaran Negara Republik Indonesia Tahun 1981 Nomor 76, Tambahan Lembaran Negara Nomor 3209).

22 Lebih lanjut lihat Pasal 97 ayat (3) Kitab Undang-Undang Hukum Acara Pidana (KUHAP) (Lembaran Negara Republik Indonesia Tahun 1981 Nomor 76, Tambahan Lembaran Negara Nomor 3209).

23 Anonim, "Hakim Perintahkan Jaksa Bebaskan Karyawan Chevron", http://www.hukumonline.com/berita/baca/lt50b4e182d6856/hakimperintahkan-jaksa-bebaskan-karyawan-chevron, diakses 3 November 2015.

24 Junaedi, "Pesan Pembaruan Hakim Sarpin", http://www.hukumonline.com/berita/baca/lt54f68621c3210/pesan-pembaruan-hakim-sarpinbroleh--junaedi--sh-msi-llm-, diakses 3 November 2015.

25 Anonim, "Lagi, Hakim perluas Objek Praperadilan", http://www.hukumonline.com/berita/baca/lt4cd2decce98cf/hakim-perluas-objekpraperadilan-, diakses 3 November 2015.

26 Putusan Mahkamah Konstitusi Nomor 21/PUU-XII/2014 perihal Pengujian Materil Undang-Undang Nomor 8 Tahun 1981 tentang Hukum Acara Pidana terhadap UUD.

$27 \quad$ Ibid., hlm. 104-108.
} 
secara limitatif oleh ketentuan Pasal 1 angka 10 juncto Pasal 77 huruf a KUHAP.

MK berpendapat dimasukkannya keabsahan penetapan tersangka sebagai objek pranata praperadilan adalah agar perlakuan terhadap seseorang dalam proses pidana memperhatikan tersangka sebagai manusia yang mempunyai harkat, martabat, dan kedudukan yang sama di hadapan hukum. Penetapan tersangka adalah bagian dari proses penyidikan yang di dalamnya kemungkinan terdapat tindakan sewenang-wenang dari penyidik yang termasuk dalam perampasan hak asasi seseorang. ${ }^{28}$

\section{Perluasan Obyek Praperadilan dalam} Beberapa Putusan Pengadilan

Berikut akan diuraikan beberapa putusan Pengadilan Negeri berhasil didapat peneliti yang memperluas kewenangan praperadilan yang akan diuraikan berdasarkan perluasan obyeknya;

\section{a. Penetapan Tersangka}

Terkait dengan obyek praperadilan berupa uji keabsahan penetapan tersangka, salah satu yang kontroversial dan menjadi perbincangan hangat adalah putusan Pengadilan Negeri Jakarta Selatan Nomor 04/Pid. Prap/2015/PN.Jkt.Sel. dengan pemohon Budi Gunawan dan dengan termohon Komisi Pemberantasan Korupsi (KPK). Putusan ini menyatakan penetapan tersangka atas Komjen Budi Gunawan oleh KPK adalah tidak sah dan tidak berdasar atas hukum.

Hal yang menarik putusan ini diputuskan sebelum Mahkamah Konstitusi memperluas obyek praperadilan. Jika ditilik dari pertimbangannya nampak jelas bahwa putusan ini memperluas juga definisi upaya paksa tidak hanya terbatas pada ketentuan Pasal 77 KUHAP. Lebih lengkap berikut isi pertimbangan hukumnya yang menyatakan bahwa:

$$
\begin{aligned}
& {[\ldots] \text { segala tindakan Penyidik dalam }} \\
& \text { proses penyidikan dan segala }
\end{aligned}
$$

tindakan Penuntut Umum dalam proses penuntutan adalah merupakan tindakan upaya paksa, karena telah menempatkan atau menggunakan label "Pro Justisia" pada setiap tindakan. [...]segala tindakan Penyidik dalam proses penyidikan dan segala tindakan Penuntut Umum dalam proses penuntutan yang belum diatur dalam Pasal 77 jo. Pasal 82 ayat (1) jo. Pasal 95 ayat (1) dan ayat (2) KUHAP, ditetapkan menjadi objek praperadilan dan lembaga hukum yang berwenang menguji keabsahan segala tindakan Penyidik dalam proses penyidikan dan segala tindakan Penuntut Umum dalam proses penuntutan adalah Lembaga Praperadilan;

[...]terkait langsung dengan permohonan Pemohon, karena "Penetapan Tersangka" merupakan bagian dari rangkaian tindakan Penyidik dalam proses penyidikan, maka lembaga hukum yang berwenang menguji dan menilai keabsahan "Penetapan Tersangka" adalah Lembaga Praperadilan. ${ }^{29}$

Dari beberapa pertimbangan di atas, jelas bahwa hakim memaknai upaya paksa sebagai tindakan apapun yang dilakukan oleh penyidik dan atau penuntut umum yang dilakukan dalam koridor label "pro-justitia". Luasnya definisi upaya paksa pro yustisia ini mengakibatkan tidak hanya penetapan tersangka yang dapat diuji oleh praperadilan namun juga dapat dimaknai sebagai segala tindakan yang memasuki dan melanggar ranah privat warga negara termasuk pemblokiran rekening, pemasangan police line dan tindakan lain.

\section{b. Pelepasan Police Line atas Fasilitas Umum}

Sama dengan putusan praperadilan yang diuraikan sebelumnya, putusan Pengadilan Negeri Jakarta Barat Nomor 04/ pid.Pra/2013/PN.JKT.BAR dengan pemohon

\footnotetext{
28 Lulu Hanifah, "MK: Penetapan Tersangka Masuk Lingkup Praperadilan", http://www.mahkamahkonstitusi.go.id/index.php?page=web. Berita\&id=10796\#.VjLpPBArK8U, diakses 3 November 2015.

29 Putusan Pengadilan Negeri Jakarta Selatan Nomor 04/Pid.Prap/2015/PN.Jkt.Sel perihal Pra Peradilan Budi Gunawan.
} 
Harjadi Jahja dan Santoso Sitorus dan dengan termohon Kepolisian Republik Indonesia ini diputus sebelum MK memperluas kewenangan praperadilan hingga soal uji keabsahan penggeledahan dan penyitaan. Putusan ini memperluas objek praperadilan hingga soal keabsahan penyitaan dan soal yang lebih teknis yaitu pemasangan police line.

Perkara ini bermula saat Kepolisian Resort Metro Jakarta Barat melakukan penyitaan dengan memberikan garis polisi (Police Line) di ruang-ruang fasilitas umum Rumah Susun yang terletak di apartemen Slipi tanpa memberikan lampiran ataupun salinan apapun termasuk Berita Acara Penyitaan kepada penghuni rumah susun terkait tujuan penyitaan untuk membuat terang suatu perkara pidana. Selanjutnya pemohon sebagai pengurus perhimpunan penghuni Rumah Susun Apartemen Slipi melakukan gugatan praperadilan atas tindakan yang dilakukan oleh penyidik Kepolisian tersebut di atas dikarenakan pemohon merasa dirugikan karena tidak dapat lagi menggunakan fasilitas umum tersebut.

Dalam putusannya hakim menyatakan bahwa tindakan Kepolisian yang melakukan penyitaan terhadap ruang-ruang fasilitas penunjang satuan rumah susun (fasum) apartemen sipil adalah tidak sah dan oleh karenanya hakim memerintahkan kepada Kepolisian agar melepas/menyerahkan ruang-ruang fasilitas penunjang satuan rumah susun (fasum) yang menyegel pintu masuk serta mencabut garis polisi penyitaan diruang serbaguna tersebut saat itu juga setelah putusan dibacakan; terakhir hakim juga memutuskan untuk mengembalikan kekuasaan, kewenangan atas ruang-ruang fasilitas penunjang satuan rumah susun apartemen sipil (Fasum) yang dilakukan penyitaan berupa penyegelan dengan garis polisi di lantai dasar tower (apartemen sipil kepada pemohon dan untuk kembali dapat digunakan sebagaimana mestinya oleh penghuni sebagaimana Undang-undang yang berlaku. ${ }^{30}$

Amar putusan praperadilan ini menunjukkan bahwa selain hakim memperluas obyek kewenangan praperadilan dalam hal penyitaan, juga memasukkan tindakan pemasangan segel (police line) sebagai tindakan yang dapat diuji oleh praperadilan. Padahal jika dilihat dalam Peraturan Kapolri Nomor 10 Tahun 2009 tentang Tata Cara dan Persyaratan Permintaan Pemeriksaan Teknis Kriminalistik Tempat Kejadian Perkara dan Laboratoris Kriminalistik Barang Bukti Kepada Laboratorium Forensik Kepolisian Negara Republik Indonesia, pemasangan police line sejatinya tidak ditujukan untuk melakukan tindakan penyitaan. Police line dipasang untuk kepentingan pengamanan Tempat Kejadian Perkara demi pemeriksaan barang bukti. ${ }^{31}$ Meskipun demikian, dalam putusannya hakim berpandangan pemasangan police line tersebut merugikan kepentingan pemohon dan harus dinyatakan sah melalui lembaga praperadilan.

\section{c. Penyitaan, Penggeledahan dan Pem- blokiran Rekening}

Berbeda dengan 2 (dua) putusan praperadilan sebelumnya, putusan yang akan dibahas dalam poin 3 ini diputus pasca putusan MK Nomor 21/PUU-XII/2014. Peneliti menemukan putusan MK tersebut nampaknya tidak hanya berimplikasi pada perluasan obyek praperadilan terbatas pada penetapan tersangka, penggeledahan dan

Putusan Pengadilan Negeri Jakarta Barat Nomor 04/pid.Pra/2013/PN.JKT.BAR perihal praperadilan Harjadi Jahja dan Santoso Sitorus.

Lihat Pasal 22, 34, 38 dan 96 Peraturan Kepala Kepolisian Negara Republik Indonesia Nomor 10 Tahun 2009 tentang Tata Cara dan Persyaratan Permintaan Pemeriksaan Teknis Kriminalistik Tempat Kejadian Perkara dan Laboratoris Kriminalistik Barang Bukti Kepada Laboratorium Forensik Kepolisian Negara Republik Indonesia (Berita Negara Republik Indonesia Tahun 2009 Nomor 311). 
penyitaan namun juga berimplikasi pada tindakan lain yang dilakukan oleh penyidik kepada tersangka.

Dalam Putusan Pengadilan Negeri Jakarta Selatan Nomor 32/Pid.Prap/2015/ PN.Jkt.Sel dengan Pemohon Dr. H. Ilham Arief Sirajuddin, MM, dan dengan termohon Komisi Pembertantasan Korupsi (KPK) selain memutus tentang keabsahan penetapan tersangka, penyitaan dan penggeledahan, hakim memperluas kewenangan praperadilan hingga dalam hal pengujian keabsahan pemblokiran rekening. Lebih lanjut berikut uraian pertimbangannya:

Menimbang bahwa TERMOHON sampai dengan surat Perintah Penyidikan kedua bukti T-6, tidak dapat menunjukan bukti awal yang sah minimal 2 (dua) alat bukti,

a) Termohon tidak dapat menunjukan bukti Berita Acara Pemeriksaan saksi yang ada tanda pro justisianya.

b) Termohon tidak dapat mengajukan bukti surat

c) Termohon tidak dapat menunjukan bukti telah dilakukan pemeriksaan calon tersangka yang ada pro justisianya.

d) Termohon tidak dapat menunjukan telah ditemukan bukti petunjuk bukti adanya petunjuk menurut hukum acara tindak pidana korupsi.

e) Termohon tidak dapat menunjukan adanya bukti pemeriksaan saksi ahli yang telah didengar pendapat ahli yang ada pro justicianya. ${ }^{32}$

Menimbang bahwa oleh karena penetapan Tersangka tidak memenuhi syarat tentang ditemukan 2 alat bukti sah pada tahap penyidikan maka Pengadilan Negeri berpendapat penetapan Pemohon sebagai tersangka oleh Pemohon tidak sah menurut hukum. ${ }^{33}$
Dalam kasus ini nampaknya dasar hakim menyatakan penetapan tersangka tidak sah adalah karena termohon KPK tidak dapat menunjukan ditemukannya minimal 2 (dua) alat bukti yang sah sesuai amar putusan MK tersebut di atas. Ketidak absahan penetapan tersangka oleh termohon KPK ini menurut hakim berimplikasi pada apapun tindakan penyidik selanjutnya, hal ini tercermin dalam pertimbangan berikut:

Menimbang bahwa oleh karena penyitaan telah dilakukan berdasarkan proses pemeriksaan perkara aquo. Bahwa bukti P-8, P-10, P-11, P-12 dan P-13 disita sehubungan dengan perkara a quo dan ternyata dalam pertimbangan hukum a quo karena tidak ditemukan alat bukti permulaan minimal 2 (dua) alat bukti sah, dan berdasarkan keterangan saksi Pemohon menerangkan bahwa dokumen yang disita tidak dikuasai oleh saksi. Bahwa penyitaan yang sah harus memuat keterangan mengenai pemilik atau yang menguasai barang yang disita dan harus ada tanda tangan dari pemilik atau yang menguasai barang tersita, maka Hakim Pengadilan Negeri berpendapat terhadap penyitaan dan penggeledahannyapun dalam perkara a quo menjadi tidak sah. ${ }^{34}$

Menimbang bahwa oleh karena penetapan Pemohon sebagai tersangka oleh Termohon dinyatakan tidak sah maka pemblokiran No. Rekening Bank Mega Cabang Makasar $\quad 085.0020 .44433402 .267$ atas nama Pemohon No. Rek 02.0020.44433402.267.00.99881. Bank Sulsel atas nama Pemohon No Rek 130201204007 dan Bank Sulawesi selatan atas mana Pemohon Rek.130.201.20717.1 Pemohon oleh Termohon yang sehubungan dengan perkara ini diyatakan tidak sah. ${ }^{35}$

Dari beberapa pertimbangan di

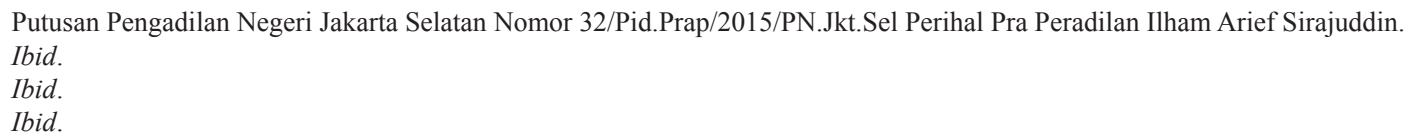


atas, nampak jelas bahwa penyitaan dan penggeledahan yang dilakukan oleh termohon KPK menjadi tidak sah dikarenakan dasar penyidikan berupa penetapan tersangka tidak dilakukan berdasarkan 2 (dua) alat bukti yang sah. Adapun yang menjadikan kasus ini menarik, hakim juga menyatakan tindakan pemblokiran rekening sebagai bagian dari upaya paksa yang bisa diuji di lembaga praperadilan. Oleh karenanya, hakim berpendapat bahwa tindakan upaya paksa berupa pemblokiran dinyatakan tidak sah atas dasar ketidakabsahan penetapan tersangka.

\section{Lembaga Praperadilan vis a vis Pemben- tukan Lembaga Hakim Pemeriksa Penda- huluan}

Riset yang dilakukan oleh Institute for Criminal Justice Reform menemukan bahwa ketidak jelasan pengaturan hukum acara praperadilan mengkibatkan sebagian besar hakim memahami mekanisme pembuktian dalam praperadilan tunduk pada hukum acara perdata yang mengutamakan kebenaran formal berupa dokumen dan atau suratsurat formal. ${ }^{36}$

Salah satu contohnya dapat ditemui dalam pertimbangan putusan praperadilan Pengadilan Negeri Jakarta selatan, hakim menegaskan percampuran mekanisme sidang peradilan perdata dan pidana dalam sidang praperadilan. Hal ini nampak dalam pertimbangan hakim dalam putusan No. 04/Pid.Pra/2009/PN. Jkt. Sel yang menyatakan:

Menimbang, bahwa gugatan praperadilan adalah perkara pidana dengan mekanisme perdata, oleh karena itu gugatan praperadilan yang diajukan adalah ke pengadilan negeri yang wilayah hukumnya meliputi tempat kedudukan hukum dari termohon.

Selain hal tersebut di atas, ICJR mencatat beberapa kelemahan praperadilan yang sangat berpengaruh pada efektifitas dan optimalisasi lembaga praperadilan sebagai satu-satunya lembaga pengawasan horizontal dalam sistem peradilan pidana yaitu: ${ }^{37}$

a. Kewenangan praperadilan hanya bersifat Post Factum

Meski hakim praperadilan dapat menyatakan sah tidaknya penangkapan, penahanan, penghentian penyidikan atau penghentian penuntutaan dan lainnya, kewenangan ini terbatas setelah upaya paksa dilakukan, dengan kata lain kewenangan praperadilan bukan pada saat hal-hal itu akan dilakukan. Sehingga, kedudukan hakim praperadilan dalam fase praajudikasi menjadi tidak efektif untuk memberikan perlindungan terhadap kekuasaan penyidik yang besar dan keliru dijalankan karena faktor peraturan perundang-undangan.

b. Pengujian upaya paksa hanya terbatas pada review administratif

Dalam praktiknya, praperadilan hanya menguji syarat-syarat upaya paksa yang bersifat formal administratif. Hakim hanya memerhatikan ada atau tidak adanya kelengkapan surat dan sama sekali tidak menguji dan menilai syarat materiilnya. Padahal syarat materiil inilah yang menentukan seseorang dapat dikenakan upaya paksa.

c. Sikap hakim yang cenderung pasif dalam praperadilan

Dalam menggunakan kewenangannya, hakim pada praperadilan bersikap pasif, yang hanya dapat dipergunakan jika ada permohonan. Hakim praperadilan menunggu adanya permohonan dari para pemohon yang merasa haknya dilanggar atau dirugikan atas tindakan hukum yang dilakukan oleh penyidik atau penuntut umum dan permohonan ganti kerugian

d. Gugurnya praperadilan yang menghilangkan hak tersangka

Menurut banyak teoritis, ketentuan tersebut tidak mencerminkan keadilan, karena dengan demikian tindakan yang dilakukan oleh pejabat yang bersangkutan tidak bisa diketahui sah menurut hukum ataukah tidak. Meskipun Hakim berwenang melaku- 
kan penahanan, namun ia tidak bisa diajukan praperadilan. Oleh karena itu, jika ada permintaan pemeriksaan praperadilan terhadap seorang Hakim, haruslah ditolak dengan surat biasa di luar sidang (SEMA No. 14 Tahun 1983).

e. Masalah manajemen perkara praperadilan dan ketepatan waktu praperadilan Jangka waktu yang terbatas hanya 7 (tujuh) hari, dimana putusan harus dijatuhkan paling lambat dalam waktu tersebut tidak diimbangi dengan manajemen perkara di pengadilan yang baik dikarenakan berbagai macam factor termasuk keengganan aparat penyidik/penuntut umum untuk datang menghadiri sidang praperadilan.

Memperhatikan beberapa kelemahan praperadilan tersebut di atas, Badan Pembinaan Hukum Nasional Kementerian Hukum dan HAM menyatakan bahwa penyusunan RKUHAP sebagai pengganti dari Undang-Undang Nomor 8 Tahun 1981 dilakukan dengan mendasarkan kepada tiga pokok persoalan, yaitu: Pertama, bagaimana upaya menguatkan dan mengimplementasikan perlindungan hukum terhadap hak asasi bagi seseorang yang diduga melakukan suatu perbuatan pidana pada setiap tahapan proses peradilan pidana dan tidak mengurangi hak hukum tersangka/ terdakwa yang telah ada. Kedua, bagaimana mewujudkan proses peradilan yang adil bagi tersangka/terdakwa dalam proses peradilan pidana dan menempatkannya sebagai kewajiban negara yang berkorelasi dengan hak mutlak bagi tersangka/ terdakwa yang tidak boleh dikurangi, dan bagaimana mewujudkan keadilan sedini mungkin bagi orang yang dirugikan akibat adanya pelanggaran hukum pidana. $^{38}$

Oleh sebab itu dalam RKUHAP 2012 model pengawasan horizontal lembaga prapradilan diganti dengan konsep Hakim Pemeriksa Pendahuluan
(HPP) yang jika dicermati konsep ini memiliki tugas serta wewenang yang lebih luas dan lengkap terhadap upaya paksa yang dilakukan oleh aparat penegak hukum dalam tahap praajudikasi jika dibandingkan dengan KUHAP saat ini. Jika dilakukan perbandingan, terdapat beberapa kelebihan dan kekurangan baik dalam pengaturan lembaga Praperadilan dalam UndangUndang Nomor 8 Tahun 1981 KUHAP jo. Putusan MK Nomor 21/PUU-XII/2014 maupun Hakim Pemeriksa Pendahuluan (HPP) yang ada dalam konsep RUU KUHAP (draft 11 Desember Tahun 2012). ${ }^{39}$

Pertama, soal kedudukan dan kewenangan, sesuai dengan namanya praperadilan dalam KUHAP berarti sebelum atau yang mendahului kegiatan peradilan. Oleh sebab itu, Praperadilan belum masuk kegiatan peradilan itu sendiri atau tidak masuk kepada substansi perkara pidana. Dalam menggunakan kewenangannya tersebut diatas, hakim praperadilan bersikap pasif dimana kewenangan yang dimiliki hakim Praperadilan hanya dapat dipergunakan apabila ada permohonan.

Dalam konsep RKUHAP 2012, kedudukan Hakim Pemeriksa Pendahuluan (HPP) terletak diantara penyidik dan penuntut umum di satu pihak dan hakim di lain pihak). Wewenang Hakim Pemeriksa Pendahuluan lebih luas dan lebih lengkap daripada lembaga praperadilan. $^{40}$ HPP memiliki tugas untuk menilai jalannya penyidikan dan penuntutan dan wewenang lain yang ditentukan dalam RKUHAP. ${ }^{41}$

Pasal 111 ayat (1) RKUHAP menguraikan kewenangan HPP yang berwenang menetapkan atau memutuskan:

a. sah atau tidaknya penangkapan, penahanan, penggeledahan, penyitaan, atau penyadapan;

b. pembatalan atau penangguhan penahanan;

\footnotetext{
38 Mudzakkir, et al., 2011, Hakim Komisaris dalam Sistem Peradilan di Indonesia, Badan Pembinaan Hukum Nasional, Jakarta, hlm. 41.

39 Komite Masyarakat Sipil untuk Pembaharuan KUHAP, "Rancangan Kitab Undang-undang Hukum Acara Pidana Draft 11 Desember 2012", http://icjrid.files.wordpress.com/2012/12/r-kuhap.pdf, diakses 12 Oktober 2015.

40 Supriyadi Widodo Eddyono dan Erasmus Napitupulu, 2014, Prospek Hakim Pemeriksa Pendahuluan dalam Pengawasan Penahanan dalam Rancangan KUHAP, Institute for Criminal Justice Reform, Jakarta, hlm. 30.

41 Penjelasan Pasal 111 ayat (3) RKUHAP.
} 
c. bahwa keterangan yang dibuat oleh tersangka atau terdakwa dengan melanggar hak untuk tidak memberatkan diri sendiri;

d. alat bukti atau pernyataan yang diperoleh secara tidak sah tidak dapat dijadikan alat bukti;

e. ganti kerugian dan/atau rehabilitasi untuk seseorang yangditangkap atau ditahan secara tidak sah atau ganti kerugian untuk setiap hak milik yang disita secara tidak sah;

f. tersangka atau terdakwa berhak untuk atau diharuskan untuk didampingi oleh pengacara;

g. bahwa penyidikan atau penuntutan telah dilakukan untuk tujuan yang tidak sah;

h. penghentian penyidikan atau penghentian penuntutan yang tidak berdasarkan asas oportunitas;

i. layak atau tidaknya suatu perkara untuk dilakukan penuntutan ke pengadilan;

j. pelanggaran terhadap hak tersangka apapun yang lain yang terjadi selama tahap penyidikan.

HPP memiliki tugas dan wewenang yang lebih luas dan lebih lengkap terhadap tindakantindakan penegak hukum pada pemeriksaan pendahuluan. Berbeda dengan praperadilan yang pasif, Selain secara pasif menerima permohonan dari tersangka atau penasihat hukumnya atau dari penuntut umum, HPP secara aktif dapat memutuskan hal-hal sebagaimana dimaksud dalam Pasal 111 ayat (1) RKUHAP atas inisiatifnya sendiri, kecuali ketentuan sebagaimana dimaksud pada ayat (1) huruf I RKUHAP. ${ }^{42}$

Dilihat dari luasnya kewenangan dan penggunaan wewenang yang dimiliki oleh HPP tersebut, secara konseptual dapat dinyatakan bahwa jaminan perlindungan hukum terhadap hak asasi tersangka/terdakwa lebih kuat dan lebih lengkap di bandingkan dengan ketentuan pada praperadilan dalam KUHAP yang saat ini berlaku. Penggunaan wewenang yang dimiliki oleh HPP yang bersifat aktif atau atas inisiatif sendiri menunjukkan bahwa
HPP memiliki tanggungjawab yang sangat besar pada tahap pendahuluan pemeriksaan perkara pidana.

Kedua, soal hukum acara. Proses beracara Praperadilan tidak diatur secara rinci tegas dalam KUHAP. Berdasarkan riset ICJR yang dikemukakan pada bagian sebelumnya, hakim praperadilan cenderung memahami bahwa hukum acara perdata lah yang menjadi dasar pemeriksaan obyek praperadilan, sehingga sebagian besar hakim hanya mendasarkan kepada kebenaran formil berupa kelengkapan dokumen atau berkas dan didukung oleh pemeriksaan saksi dengan durasi maksimal pemeriksaan 7 (tujuh) hari. Sedangkan proses beracara untuk HPP sudah diatur secara lebih rinci, dalam Pasal 112 RKUHAP dinyatakan bahwa:

(1) Hakim Pemeriksa Pendahuluan memberikan keputusan dalam waktu paling lambat 2 (dua) hari terhitung sejak menerima permohonan sebagaimana dimaksud dalam Pasal 111 ayat (2).

(2) Hakim Pemeriksa Pendahuluan memberikan keputusan atas permohonan berdasarkan hasil penelitian salinan dari surat perintah penangkapan, penahanan, penggeledahan, penyitaan, penyadapan, atau catatan lainnya yang relevan.

(3) Hakim Pemeriksa Pendahuluan dapat mendengar keterangan dari tersangka atau penasihat hukumnya, penyidik, atau penuntut umum.

(4) Apabila diperlukan, Hakim Pemeriksa Pendahuluan dapat meminta keterangan dibawah sumpah dari saksi yang relevan dan alat bukti surat yang relevan.

(5) Permohonan sebagaimana dimaksud dalam Pasal 111 ayat (2) tidak menunda proses penyidikan.

Sekilas nampak bahwa hukum acara HPP lebih baik daripada hukum acara praperadilan, HPP selain meneliti dokumen dalam rangka mencari kebenaran materiil dapat juga meminta keterangan dari tersangka atau penasihat hukumnya, penyidik, atau penuntut umum bahkan juga dapat meminta 
keterangan di bawah sumpah kepada saksi yang relevan. Namun demikian, durasi waktu yang dibatasi hanya 2 (dua) hari nampaknya akan menjadi kendala yang serius jika HPP benar-benar ingin melakukan proses pencarian kebenaran materiil melalui alat bukti yang lain. Alih-alih mencari alat bukti lain yang relevan, HPP hampir dapat dipastikan hanya akan mengandalkan kelengkapan berkas formil dalam melakukan penilaian keabsahan tindakan aparat penegak hukum mengingat durasi yang sangat pendek.

Ketiga, soal putusan dan upaya hukum. Mengenai upaya hukum, Putusan HPP adalah putusan yang bersifat final yang tidak dapat dilakukan upaya hukum. Hal ini berbeda dengan putusan hakim Praperadilan yang dalam praktiknya bisa dilakukan banding untuk putusan praperadilan terkait penghentian penyidikan atau penuntutan dan bahkan dalam beberapa kasus dapat dilakukan upaya hukum Peninjauan Kembali. ${ }^{43}$ Penetapan atau putusan Hakim Pemeriksa Pendahuluan tidak dapat diajukan upaya hukum banding atau kasasi. ${ }^{44} \mathrm{Hal}$ ini menurut peneliti merupakan kelemahan, karena kewenangan yang besar yang dimiliki oleh HPP sangat rawan untuk disalah gunakan. Seyogyanya ada mekanisme uji terakhir yang dilakukan oleh lembaga peradilan yang setingkat atau dua tingkat diatasnya untuk tetap dapat menguji isi putusan HPP.

\section{Kesimpulan}

Sebelum Mahkamah Konstitusi (MK) menjatuhkan putusan Nomor 21/PUU-XII/2014 sejatinya terdapat beberapa putusan hakim praperadilan yang juga telah yang memperluas kewenangan praperadilan dalam Pasal 77 Kitab UndangUndang Hukum Acara Pidana (KUHAP). Perluasan kewenangan ini dapat dipahami sebagai upaya kekuasaan yudisial dalam melakukan pengawasan uji keabsahan upaya paksa yang dilakukan oleh penyidik dan penuntut yang tidak terbatas pada ketentuan Pasal 1 angka 10 jo. Pasal 77 KUHAP. Hakim praperadilan dari beberapa putusan yang dianalisis oleh peneliti pada bab sebelumnya, nampaknya memandang perlu penguatan perlindungan hak azasi manusia warga negara melalui perluasan obyek upaya paksa yang dapat diuji oleh lembaga praperadilan.

Perluasan kewenangan praperadilan sebagai implikasi dari putusan MK Nomor 21/ PUU-XII/2014 yang memberikan kewenangan praperadilan untuk menguji keabsahan penetapan tersangka dapat dipahami sebagai sebuah terobosan yang baik. Namun ketidak jelasan hukum acara praperadilan khusus masalah ini mengakibatkan lembaga praperadilan dalam proses pembuktiannya berpotensi terlalu jauh masuk dan ikut menguji pokok perkara yang harusnya baru diuji di proses pembuktian di persidangan. Oleh karenanya, peraturan pemerintah yang mengatur hukum acara praperadilan penting untuk segera dibuat.

Dengan segala kelebihan dan kekurangannya sebagaimana telah dikemukakan sebelumnya, lembaga praperadilan terbukti kurang efektif dalam menjalankan fungsi pengawasan dalam sistem peradilan pidana Indonesia, hal inilah yang mendorong pembuat Undang-Undang dalam beberapa Rancangan Kitab Undang-Undang Hukum Acara Pidana (RKUHAP) untuk memasukkan kembali konsep Lembaga Hakim Pemeriksa Pendahuluan (HPP) yang secara aktif memiliki kewenangan lebih dalam melakukan pengawasan terhadap aparat dalam sistem peradilan pidana. HPP ini diharapkan dapat lebih menjamin hak asasi manusia warga negara yang berhadapan dan atau yang berkonflik dengan hukum di masa mendatang.

\footnotetext{
43 Surat Edaran Mahkamah Agung Nomor 4 Tahun 2014 tentang Pemberlakuan Rumusan Hasil Rapat Pleno Kamar Mahkamah Agung Tahun 2013 sebagai Pedoman Pelaksanaan Tugas bagi Pengadilan menyatakan bahwa PK terhadap praperadilan diperbolehkan jika ditemukan indikasi penyelundupan hukum.

44 Pasal 122 RKUHAP.
} 


\section{DAFTAR PUSTAKA}

\section{A. Buku}

Anggara, et al., 2014, Praperadilan di Indonesia: Teori, Sejarah dan Praktiknya, Institute for Criminal Justice Reform, Jakarta.

Atmasasmita, Romli, 2011, Sistem Peradilan Pidana Kontemporer, Kencana Prenada Media Group, Jakarta.

Biro Hukum, 1981, Undang-Undang Hukum Acara Pidana dan Proses Pembahasannya, Departemen Penerangan RI, Jakarta.

Eddyono, Supriyadi Widodo dan Napitupulu, Erasmus, 2014, Prospek Hakim Pemeriksa Pendahuluan dalam Pengawasan Penahanan dalam Rancangan KUHAP, Institute for Criminal Justice Reform, Jakarta.

Harahap, M Yahya, 2007, Pembahasan dan Permasalahan dan Penerapan KUHAP (Penyidikan dan Penuntutan), Sinar Grafika, Jakarta.

Hamzah, Andi dan Surachman, 2015, Pre-Trial Justice and Discretionary Justice dalam KUHAP Berbagai Negara, Sinar Grafika, Jakarta.

Hart, A.C.'t, et al., Hukum Acara Pidana (dalam Prespektif Hak Asasi Manusia), LBH Jakarta, Jakarta .

Ibrahim, Johni , 2007, Teori dan Metodologi Penelitian Hukum Normatif, Bayu Media Publishing, Malang.

Loeqman, Loebby, 1987, Pra Peradilan di Indonesia, Ghalia Indonesia, Jakarta. 2002, Hak Asasi Manusia (HAM) dalam Hukum Acara Pidana (HAP), Datacom, Jakarta.

Mulyadi, Lilik, 2007, Hukum Acara Pidana Normatif, Teoritis, Praktik, dan Pemasalahannya, Alumni, Bandung.

Mudzakkir, et al., 2011, Hakim Komisaris dalam Sistem Peradilan di Indonesia, Badan Pembinaan Hukum Nasional, Jakarta.

\section{B. Artikel Jurnal}

Strang, Robert R, "More Adversarial, But Not Completely Adversarial: Reformasi of the Indonesian Criminal Procedure Code", Fordham International Law Journal, Vol. 32, No. 188, 2008.

\section{Internet}

Anonim, "Penelitian KHN: Praperadilan Mengandung Banyak Kelemahan”, http://www.hukumonline.com/berita/ baca/lt4b29bab9ef3a7/penelitian-khnpraperadilan-mengandung-banyakkelemahan, diakses 12 Oktober 2015.

Anonim, "Metamorfosis Wajah Praperadilan", http://www.hukumonline.com/berita/baca/ lt55716335453cd/metamorfosis-wajahpraperadilan, diakses 25 September 2015.

Anonim, "Putusan Praperadilan Komjen BG Kontroversial MA Harus Berani Mengujinya", http://news.detik.com/berita/ 2841011/putusan-praperadilan-komjen-bgkontroversial-ma-harus-berani-mengujinya, diakses 12 Oktober 2015.

Anonim, "Hakim Perintahkan Jaksa Bebaskan Karyawan Chevron", http:// www.hukumonline.com/berita/bacal lt50b4e182d6856/hakim-perintahkan-jaksabebaskan-karyawan-chevron, diakses 3 November 2015.

Anonim, "Lagi, Hakim Perluas Objek Praperadilan", http://www.hukumonline.com/berita/baca/ lt4cd2decce98cf/hakim-perluas-objekpraperadilan-, diakses 3 November 2015.

Junaedi, "Pesan Pembaruan Hakim Sarpin", http://www.hukumonline.com/berita/baca/ lt54f68621c3210/pesan-pembaruan-hakimsarpin-broleh--junaedi--sh-msi-llm-, diakses 3 November 2015.

Komite Masyarakat Sipil untuk Pembaharuan KUHAP, "Rancangan Kitab Undang-undang 
Hukum Acara Pidana Draft 11 Desember 2012", ～http://icjrid.files.wordpress.com/ 2012/12/r-kuhap.pdf, diakses 12 Oktober 2015

Lulu Hanifah, "MK: Penetapan Tersangka Masuk Lingkup Praperadilan", http://www.mahkamahkonstitusi.go.id/ index.php?page $=$ web.Berita\&id $=10796 \#$. VjLpPBArK8U, diakses 3 November 2015.

Muhammad Khairur Rasyid, "Kontras Gelar Perkara Terbuka Korban Kriminalisasi", http://Jatim. Metrotvnews.Com/Read/2015/09/15/431457/ Kontras-Gelar-Perkara-Terbuka-KorbanKriminalisasi, diakses 12 Oktober 2015.

Moyang Kasih Dwimerdeka, "36 RUU Lama Kembali Masuk Prolegnas 2015”, http://nasional.tempo. co/read/news/2015/02/03/078639666/36ruu-lama-kembali-masuk-prolegnas-2015, diakses 25 September 2015.

\section{Peraturan Perundang-Undangan}

Kitab Undang-Undang Hukum Acara Pidana (KUHAP) (Lembaran Negara Republik Indonesia Tahun 1981 Nomor 76, Tambahan Lembaran Negara Republik Indonesia Nomor 3209).

\section{E. Putusan Pengadilan}

Putusan Pengadilan Negeri Jakarta Selatan Nomor 04/Pid.Prap/2015/PN.Jkt.Sel perihal Pra Peradilan Budi Gunawan.

Putusan Pengadilan Negeri Jakarta Barat Nomor 04/ pid.Pra/2013/PN.JKT.BAR perihal praperadilan Harjadi Jahja dan Santoso Sitorus.

Peraturan Kepala Kepolisian Negara Republik Indonesia Nomor 10 Tahun 2009 Tentang Tata Cara dan Persyaratan Permintaan Pemeriksaan Teknis Kriminalistik Tempat Kejadian Perkara dan Laboratoris Kriminalistik Barang Bukti Kepada Laboratorium Forensik Kepolisian Negara Republik Indonesia (Berita Negara Republik Indonesia Tahun 2009 Nomor 311).

Putusan Pengadilan Negeri Jakarta Selatan Nomor 32/Pid.Prap/2015/PN.Jkt.Sel Perihal Pra Peradilan Ilham Arief Sirajuddin.

Surat Edaran Mahkamah Agung Nomor 4 Tahun 2014 Tentang Pemberlakuan Rumusan Hasil Rapat Pleno Kamar Mahkamah Agung Tahun 2013 sebagai Pedoman Pelaksanaan Tugas Bagi Pengadilan.

\section{F. Lain-Lain}

Rancangan Kitab Undang-Undang Hukum Acara Pidana (RKUHAP) Tahun 2014. 